Table. Summary of treatment-emergent AEs

\begin{tabular}{|c|c|c|c|}
\hline $\begin{array}{l}n(\%) \\
\text { [number of events per } \\
100 \text { PYs] }\end{array}$ & $\begin{array}{c}\text { Group } 1 \\
\text { Withdrew csDMARD } \\
\text { during Wks 0-96 } \\
(\mathrm{N}=42) \\
{[\mathrm{PYs}=104]}\end{array}$ & $\begin{array}{c}\text { Group } 2 \\
\text { Continued csDMARD } \\
\text { during Wks 0-96 } \\
(\mathrm{N}=1851) \\
{[\mathrm{PYs}=5870]}\end{array}$ & $\begin{array}{c}\text { Group } 3 \\
\text { Sarilumab } \\
\text { monotherapy } \\
(\mathrm{N}=111) \\
{[\mathrm{PYs}=230]}\end{array}$ \\
\hline ny $A E$ & 41 (97.6) [225] & $1626(87.8)$ [184] & $83(74.8)[138$ \\
\hline Serious $A E$ & 17 (40.5) [17] & 475 (25.7) [13] & $16(14.4)[10]$ \\
\hline AEs leading to & 15 (35.7) [16] & 382 (20.6) [7] & 8 (7.2) [3] \\
\hline
\end{tabular}

sarilumab

discontinuation

Acknowledgement: Study funding and medical writing support (Matt Lewis, Adelphi) provided by Sanofi and Regeneron Pharmaceuticals, Inc.

Disclosure of Interests: Jeffrey R. Curtis Grant/research support from: Abbvie, Amgen, BMS, Corrona, Janssen, Lilly, Myriad, Pfizer, Roche/ Genentech, UCB, Consultant for: Abbvie, Amgen, BMS, Corrona, Janssen, Lilly, Myriad, Pfizer, Roche/Genentech, UCB, Yong Lin Shareholder of: Sanofi, Employee of: Sanofi, Karthinathan Thangavelu Shareholder of: Sanofi, Employee of: Sanofi, Marina Stanislav Consultant for: RPharm, Gregory St. John Shareholder of: Regeneron Pharmaceuticals, Inc, Employee of: Regeneron Pharmaceuticals, Inc, Antonio Gómez-Centeno Grant/research support from: Boehringer Ingelheim, Celltrion, Galapagos-Gilead, Lilly, Novartis, Pfizer, Roche, Sanofi, UCB, YL Biologics, Consultant for: Abbvie, Biogen, BMS, Celgene, Gebro, Hospira, Lilly, MSD, Pfizer, Roche, Rubio, Sandoz, Sanofi, Speakers bureau: Abbvie, BMS, Gebro, Janssen, Lilly, Menarini, MSD, Pfizer, Roche, Rubio, UCB, Sanofi, Carlo Selmi Grant/research support from: AbbVie, Janssen, MSD, Novartis, Pfizer, Consultant for: AbbVie, Alfa-Sigma, Biogen, Bristol-Myrs Squibb, Celgene, Eli-Lilly, Janssen, Merck Sharp and Dohme, Novartis, Pfizer, Roche, Sanofi-Genzyme, UCB, Speakers bureau: AbbVie, AlfaSigma, Biogen, Bristol-Myrs Squibb, Celgene, Eli-Lilly, Janssen, Merck Sharp and Dohme, Novartis, Pfizer, Roche, Sanofi-Genzyme, UCB, Thomas Huizinga Consultant for: Merck, UCB, Bristol Myers Squibb, Biotest AG, Pfizer, GSK, Novartis, Roche, Sanofi-Aventis, Abbott, Crescendo Bioscience Inc., Nycomed, Boeringher, Takeda, Zydus, Epirus, Eli Lilly, José Antonio Maldonado-Cocco Consultant for: Pfizer, Merck Sharp Dohme, Sanofi - Aventis, Novartis, Bristol Myers Squibb, Roche, Boehringer Ingelheim, Schering - Plough, Abbott, UCB, Eli Lilly, Gilead, Speakers bureau: Pfizer, Merck Sharp Dohme, Sanofi - Aventis, Novartis, Bristol Myers Squibb, Roche, Boehringer Ingelheim, Schering Plough, Abbott, UCB, Eli Lilly., Marwan Bukhari Speakers bureau: Bristol-Myers Squib, UCB celltech, Roche/Chugai, Pfizer, Abbvie, Merck, Mennarini, Sanofi-aventis, Eli-Lilly, Janssen and Novartis., Frank Buttgereit: None declared

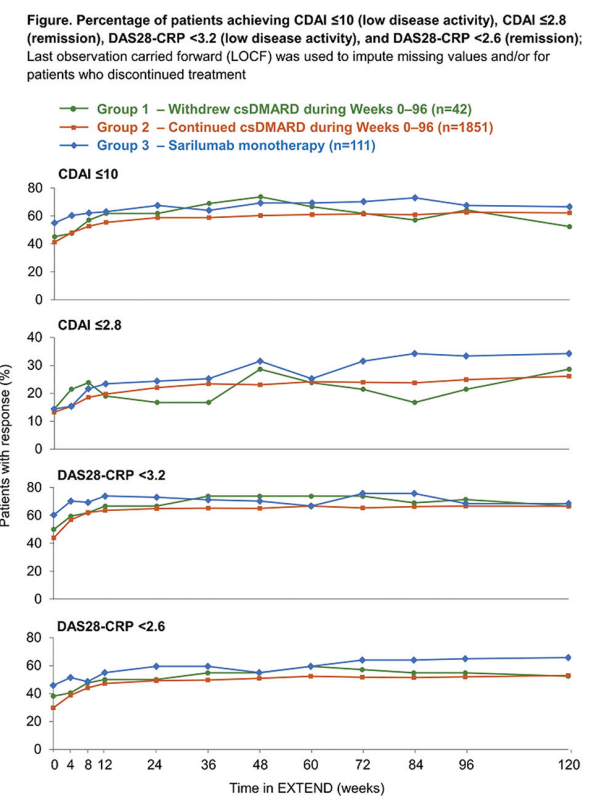

DOI: 10.1136/annrheumdis-2019-eular.740

\section{FRI0082 EFFECTIVENESS OF TNF INHIBITORS VS. NON-TNF INHIBITORS (ABATACEPT, TOCILIZUMAB AND RITUXIMAB) AFTER FAILURE OF NON-TNFI BIOLOGIC DMARD IN RHEUMATOID ARTHRITIS - COLLABORATION BETWEEN FIVE NATIONAL REGISTERS}

Katerina Chatzidionysiou ${ }^{1}$, Merete L. Hetland ${ }^{2}$, Thomas Frisell ${ }^{1}$, Daniela DI Giuseppe ${ }^{1}$, Karin Hellgren ${ }^{1}$, Bente Glintborg ${ }^{2}$, Dan Nordström ${ }^{3}$, Kalle Aaltonen ${ }^{4}$ Nina Trokovic ${ }^{3}$, Eirik Kristianslund ${ }^{5}$, Tore K. Kvien ${ }^{5}$, Sella Aarrestad Provan ${ }^{5}$, Björn Gudbjornsson ${ }^{6}$, Gerdur Gröndal ${ }^{6}$, Lene Dreyer ${ }^{2}$, Lars Erik Kristensen², Tanja Schjødt Jørgensen ${ }^{2}$, Lennart T.H. Jacobsson ${ }^{7}$, Johan Askling ${ }^{1} .{ }^{1}$ Clinical Epidemiology Section, Karolinska Institute, Stockholm, Sweden; ${ }^{2}$ On behalf of the DANBIO registry, Copenhagen, Denmark; ${ }^{3}$ Helsinki Univ and Hospital, Helsinki, Finland; ${ }^{4}$ Pharmaceuticals Pricing Board, Ministry of Social Affairs and Health, Helsinki, Finland; ${ }^{5}$ Dep of Rheum, Diakonhjemmet Hospital, Oslo, Norway; ${ }^{6}$ Centre for Rheum Research, Univ of Iceland, Reykjavik, Iceland; ${ }^{3}$ Sahlgrenska Academy at Univ of Gothenburg, Gothenburg, Sweden

Table 1. Baseline (=start of $2^{\text {nd }}$ bDMARD) characteristics of RA patients who switched to a $2^{\text {nd }}$ bDMARD after a non-TNFi and clinical effectiveness. Results are not shown when $\mathrm{N}<20$.

\begin{tabular}{|c|c|c|c|c|c|c|c|c|c|c|c|c|}
\hline $\begin{array}{l}1^{\text {st }} \rightarrow 2^{\text {nd }} \\
\text { bDMARD }\end{array}$ & $\begin{array}{c}\mathrm{N} . \\
\text { patients }\end{array}$ & $\begin{array}{l}\text { Age,years } \\
\text { (mean, SD) }\end{array}$ & $\begin{array}{l}\text { Sex (\% } \\
\text { female) }\end{array}$ & $\begin{array}{c}\text { Disease } \\
\text { duration, years } \\
\text { (median, (IQR) }\end{array}$ & $\begin{array}{l}\text { RF } \\
(\% \\
\text { pos) }\end{array}$ & $\begin{array}{l}\text { Anti- } \\
\text { CCP } \\
\text { (\%pos) }\end{array}$ & $\begin{array}{l}\text { Concomitant } \\
\text { csDMARDs } \\
(\%)\end{array}$ & $\begin{array}{l}\text { Concomitant } \\
\text { GCs } \\
(\%)\end{array}$ & $\begin{array}{l}\text { DAS28 } \\
\text { baseline } \\
\text { (mean, } \\
\text { SD) }\end{array}$ & $\begin{array}{c}\text { DAS28 } 6 \\
\text { months } \\
\text { (mean, SD) }\end{array}$ & $\begin{array}{c}\text { DeltaDAS28 } \\
0-6 \mathrm{~m}\end{array}$ & $\begin{array}{c}\mathrm{N}(\%) \text { of patients still on } \\
\text { drug at month } 6 \text { from start of } \\
2^{\text {nd }} \text { bDMARD }\end{array}$ \\
\hline $\mathrm{ABA} \rightarrow \mathrm{TNFi}$ & 185 & $56.1(13.1)$ & 77.8 & $4(2-10)$ & 73.5 & 64.1 & 74.1 & 21.1 & $\begin{array}{c}4.4 \\
(1.3)\end{array}$ & $3.5(1.3)$ & $\begin{array}{c}-0.9(1.5) \\
\mathrm{N}=126\end{array}$ & 109 (59\%) \\
\hline $\mathrm{ABA} \rightarrow \mathrm{RTX}$ & 22 & 57.7 (17.9) & 72.7 & $4.3(2-7.6)$ & 71.4 & 100 & 40.9 & 31.8 & $\begin{array}{c}4.5 \\
(1.0)\end{array}$ & \multicolumn{2}{|c|}{$\mathrm{N}<20$} & 19 (86\%) \\
\hline $\mathrm{ABA} \rightarrow \mathrm{TCZ}$ & 37 & $59.4(11.1)$ & 86.5 & $6.3(2.6-11.9)$ & 73.5 & 54.5 & 29.7 & 32.4 & $\begin{array}{c}4.9 \\
(1.3)\end{array}$ & $3.3(1.3)$ & $\mathrm{N}<20$ & $21(57 \%)$ \\
\hline $\mathrm{RTX} \rightarrow \mathrm{ABA}$ & 56 & $64.3(12.6)$ & 83.9 & $12.3(4.9-21.4)$ & 83.6 & 57.1 & 50.0 & 39.3 & $\begin{array}{c}4.4 \\
(1.3)\end{array}$ & $3.8(1.4)$ & $\begin{array}{c}-0.7(0.9) \\
\mathrm{N}=22\end{array}$ & 35 (63\%) \\
\hline $\mathrm{RTX} \rightarrow \mathrm{TNFi}$ & 99 & $60.1(12.9)$ & 76.8 & $8.1(3-14.2)$ & 76.8 & 82.4 & 53.5 & 42.4 & $\begin{array}{l}5.2 \\
(1.3)\end{array}$ & $3.6(1.4)$ & $\begin{array}{c}-1.5(1.4) \\
\mathrm{N}=44\end{array}$ & $64(65 \%)$ \\
\hline $\mathrm{RTX} \rightarrow \mathrm{TCZ}$ & 31 & $60.2(11.6)$ & 87.1 & $6.7(3-21.5)$ & 75 & 66.7 & 41.9 & 58.1 & $\begin{array}{c}5.6 \\
(1.1)\end{array}$ & $3.3(1.1)$ & $\mathrm{N}<20$ & $21(68 \%)$ \\
\hline $\mathrm{TCZ} \rightarrow \mathrm{ABA}$ & 29 & $55.9(14.6)$ & 86.2 & $5.0(2.3-14.8)$ & 65.5 & 80 & 31.0 & 20.7 & $\begin{array}{c}4.5 \\
(1.4)\end{array}$ & $3.9(1.3)$ & $\mathrm{N}<20$ & $18(62 \%)$ \\
\hline $\mathrm{TCZ} \rightarrow \mathrm{TNFi}$ & 131 & $57.6(12.8)$ & 84 & $4.0(2-8.1)$ & 77 & 71.4 & 36.6 & 24.4 & $\begin{array}{c}3.9 \\
(1.4)\end{array}$ & $3.5(1.4)$ & $\begin{array}{c}-0.5(1.6) \\
\mathrm{N}=80\end{array}$ & $83(64 \%)$ \\
\hline $\mathrm{TCZ} \rightarrow \mathrm{RTX}$ & 15 & $60.8(14.6)$ & 73.3 & $4.0(1.9-13.8)$ & 92.9 & 100 & 40.0 & 26.7 & $\begin{array}{c}4.4 \\
(2.3)\end{array}$ & $\mathrm{N}<20$ & $\mathrm{~N}<20$ & $11(73 \%)$ \\
\hline
\end{tabular}


Background: The optimal sequencing of biologic Disease Modifying AntiRheumatic Drugs (bDMARDs) in Rheumatoid Arthritis (RA) is unknown. Evidence regarding the effectiveness of a $2^{\text {nd }}$ non-TNFi bDMARD, as well as of TNFi, in patients whose $1^{\text {st }}$ bDMARD has been a non-TNFi is limited.

Objectives: To characterize patients switching for medical reasons after failure of a non-TNFi used as $1^{\text {st }}$ bDMARD, and to assess the effectiveness of rituximab (RTX), abatacept (ABA) or tocilizumab (TCZ) vs. a TNFi.

Methods: Patients from 5 national registers (Sweden, Norway, Denmark, Iceland and Finland) with RA who started treatment with a non-TNFi as a $1^{\text {st }}$ bDMARD after 2010 and switched to a $2^{\text {nd }}$ bDMARD within 3 months after the discontinuation of the $1^{\text {st }}$ (with the exception of RTX for which a 6-month window was used), were identified. Clinical effectiveness was assessed by DAS28 change at 6 months.

Results: 611 patients were included in the analyses. $80 \%$ were female, the majority were positive for RF (76\%) and anti-CCP (69\%). The mean $( \pm S D)$ age, DAS28 and $\mathrm{HAQ}$ at baseline was 58 (13), 4.5 (1.4) and 1.3 (0.7), respectively, while the median (IQR) disease duration was 5.0 (2.212.0) years. Baseline characteristics of patients and the clinical response for each switching strategy are shown in table 1. Moderate responses were observed for most switching strategies. $63 \%$ of patients were still on treatment with their $2^{\text {nd }}$ bDMARD at 6 months after switch.

Conclusion: The six-month drug retention for a $2^{\text {nd }}$ bDMARD in patients with RA switching due to failure of a non-TNFi bDMARD as $1^{\text {st }}$ ever bDMARD was lower than two thirds (63\%). More detailed analyses are exploring potential subgroups of patients for whom specific switching strategies are more effective.

Acknowledgement: The study was partly funded by a study grant from NordForsk and Foreum.

Disclosure of Interests: Katerina Chatzidionysiou: None declared, Merete L. Hetland Grant/research support from: BMS, MSD, AbbVie, Roche Novartis, Biogen, Pfizer, Consultant for: Eli Lilly, Speakers bureau: Orion Pharma, Biogen, Pfizer, CellTrion, Merck, Samsung Bioepis, Thomas Frisell: None declared, Daniela Di Giuseppe: None declared, Karin Hellgren: None declared, Bente Glintborg Grant/research support from: Biogen, Pfizer, AbbVie, Dan Nordström Grant/research support from: MSD, Pfizer, Consultant for: AbbVie, BMS, MSD, Novartis, Roche Pfizer, UCB, Speakers bureau: Novartis, UCB, Kalle Aaltonen: None declared, Nina Trokovic: None declared, Eirik kristianslund: None declared, Tore K. Kvien Grant/research support from: AbbVie, BMS, MSD, Pfizer, Roche and UCB., Consultant for: AbbVie, Biogen, BMS, Boehringer Ingelheim, Celgene, Celltrion, Eli Lilly, Hospira, Merck-Serono, MSD, Novartis, Oktal, Orion Pharma, Pfizer, Roche, Sandoz, Sanofi, Mylan and UCB, Speakers bureau: AbbVie, Biogen, BMS, Boehringer Ingelheim, Celgene, Celltrion, Eli Lilly, Hospira, Merck-Serono, MSD, Novartis, Oktal, Orion Pharma, Pfizer, Roche, Sandoz, Sanofi and UCB, Sella Aarrestad Provan Consultant for: Novartis, Speakers bureau: Lilly, Björn Gudbjornsson: None declared, Gerdur Gröndal : None declared Lene Dreyer Consultant for: MSD, UCB and Janssen Pharmaceuticals, Speakers bureau: MSD, UCB and Janssen Pharmaceuticals, Speakers bureau: UCB, MSD, Eli Lilly and Janssen Pharmaceuticals., Lars Erik Kristensen Grant/research support from: UCB, Biogen, Janssen Pharmaceuticals, and Novartis, Consultant for: Consultant for AbbVie, Amgen, Biogen, BMS, Celgene, Eli Lilly, Janssen Pharmaceuticals, MSD, Novartis, Pfizer, Roche, Sanofi, and UCB Pharma., Speakers bureau: Pfizer, AbbVie, Amgen, UCB, BMS, Biogen, MSD, Novartis, Eli Lilly and Company, and Janssen Pharmaceuticals, Tanja Schjødt Jørgensen Consultant for: Abbvie, Roche, Novartis, UCB, Biogen, Eli Lilly., Speakers bureau: Abbvie, Roche, Novartis, UCB, Biogen, Eli Lilly., Lennart T.H. Jacobsson Consultant for: $L J$ has received lecture and consulting fees from Pfizer, Abbvie, Novartis, Eli-Lily and Janssen, Johan Askling Grant/research support from: Karolinska Institutet (JA) has or has had research agreements with the following pharmaceutical companies, mainly in the context of the ATRIS national safety monitoring programme for rheumatology biologicals: Abbvie, BMS, MSD, Eli Lilly, Pfizer, Roche, Samsung Bioepis, and UCB., Consultant for: Karolinska Institutet has received remuneration for JA participating in ad boards arranged by Lilly, Novartis, and Pfizer.

DOI: 10.1136/annrheumdis-2019-eular.7095

\section{FRI0083 \\ IS A HIGH LEVEL OF IGA PREDICTIVE OF THE EFFICACY AND TOLERANCE OF RITUXIMAB DURING RHEUMATOID ARTHRITIS NAIVE OF PRIOR BIOLOGICAL TREATMENTS?}

nada cherkaoui, Imane El Bouchti. CHU med 6, rheumatology, marrakesh, Morocco

Background: The elevation of immunoglobulin A levels during rheumatoid arthritis is not an exceptional situation although not as commonly found in spondyloarthritis. Hypothetically, this elevation should translate into multiple clinical as well as biological significance.

Objectives: The objective of the study is to identify whether or not a high level of $\lg \mathrm{A}$ would have an effect on the tolerance and response of rheumatoid arthritis treated with Rituximab.

Methods: This is a retrospective study within which a total number of 33 patients with rheumatoid arthritis treated with Rituximab has been collected, whose peculiarity is the naivety to biological treatment (anti-TNF as it happens). We used regression models of Cox with univariate and multivariate analysis. The main criteria of judgment for efficiency were the EULAR response at 6 months treatment and the recourse to another cycle of rituximab. As regards tolerance, the existence of at least one adverse effect of an infectious, paradoxical or other nature constituted the eligibility argument

Results: 33 patients were included, the average age was 47.46 years. $87.9 \%$ of patients were of female gender to $12.1 \%$ of male gender. All the patients had structural articular damage. The average initial DAS28 was 6.08. The average DAS28 at 6 months of treatment was 2.98 .

13 patients had to go under the use of another cycle of rituximab and an average period of 16.8 months was observed between the 1 st and 2nd courses of treatment. $75.8 \%$ of the patients achieved a good EULAR response at 6 months. The average serum levels of $\operatorname{lgA}$ were $3.86 \mathrm{~g} / \mathrm{L}$ (1.20-7.29). $33.3 \%$ of the patients showed at least one adverse effect. High IgA levels were significantly correlated with recourse to Rituximab retreatment ( $p<0.005)$, to prior tuberculosis infection and also to the increase of Alpha 2 globulins on the electrophoresis of blood proteins We could not prove a relationship between high levels of $\lg A$ and the occurrence of side effects.

Conclusion: Polyclonal elevation of $\lg A$ during rheumatoid arthritis is possible, although rare. Theoretically, several clinical eventualities should be sought in similar situations. Such as, the existence of a positive rheumatoid factor IgA Isotype, a chronic infection, Spondyloarthropathy, or associated celiac disease. More rarely, a lupus or a Sjogren syndrom. In our series, the existence of high levels of $\lg A$ was significantly correlated with recourse to rituximab retreatment, suggesting that there is an under lying entity or a particular etiopathogenic leading to incomplete anti CD20 response. At the same time, a history of tuberculosis and high levels of alpha-2-globulin also correlated with high $\lg \mathrm{A}$ levels suggesting the existence of an infection with inflammatory reaction of chronic type.

\section{REFERENCES:}

[1] Sellam J, Rouanet S, Hendel-Chavez H, et al. CCL19, a B cell chemokine, is related to the decrease of blood memory $B$ cells and predicts the clinical response to rituximab in patients with rheumatoid arthritis. Arthritis Rheum 2013;65:2253-61.

[2] -de Jong TD, Sellam J, Agca R, et al. A multi-parameter response prediction model for rituximab in rheumatoid arthritis. Joint Bone Spine 2018;85:219-26

[3] Stradner MH, Dejaco C, Brickmann K, Graninger WB, et al. A combination of cellular biomarkers predicts failure to respond to rituximab in rheumatoid arthritis: a 24-week observational study. Arthritis Res Ther 2016;18:190.

[4] Vital EM, Dass S, Rawstron AC, et al. Management of nonresponse to rituximab in rheumatoid arthritis: predictors and outcome of re-treatment. Arthritis Rheum 2010;62:1273-9

[5] Jorgensen C, Anaya JM, Cognot C, Sany J. Rheumatoid arthritis associated with high levels of immunoglobulin A: clinical and biological characteristics. Clin Exp Rheumatol 199 I; 10:571-5

[6] Cowling E Ebringer P, Ebringer A. Association of inflammation with raised serum IgA in ankylosing spondylitis. Ann Rheum Dis 1980; 39:545-9

Disclosure of Interests: None declared

DOI: 10.1136/annrheumdis-2019-eular.6068

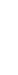

\section{(1)}

(1)

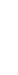

西

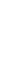

政 